\author{
Doi 10.5943/ppq/8/1/9 \\ Copyright $\odot$ Agriculture College, Guizhou University
}

\title{
First report of the rust fungus Phragmidium mexicanum from Khyber Pakhtunkhwa, Pakistan
}

\author{
Fahad M*, Fiaz M, Ullah S, Rehman HU, Shariq M, Majid A and Alam J \\ Department of Botany, Hazara University Mansehra, Khyber Pakhtunkhwa, Pakistan 21300.
}

Fahad M, Fiaz M, Ullah S, Rehman H, Shariq M, Majid A, Alam J 2018 - First report of the rust fungus Phragmidium mexicanum from Khyber Pakhtunkhwa, Pakistan. Plant Pathology \& Quarantine 8(1), 63-66, Doi 10.5943/ppq/8/1/9

\begin{abstract}
During a survey of rust fungi in Shangla and Battagram Districts of Khyber Pakutunkhwa, Pakistan, Phragmidium mexicanum on Duchesnea indica was collected and described as a new record for Pakistan. This study has raised the number of reported rust taxa of Khyber Pakutunkhwa to 181 .
\end{abstract}

Key words - Battagram - Shangla - taxonomy - Phragmidium

\section{Introduction}

Khyber Pakhtunkhwa (KP), formerly known as the Northwest Frontier Province (NWFP), is one of five Provinces of Pakistan, located in the Northwest of the country. It is situated at approximately $34.00^{\circ} \mathrm{N} 71.32^{\circ} \mathrm{E}$. The area is famous for hill coniferous forests, herbal plants, and large biodiversity. This is a floristically rich area with many plant diseases such as leaf blights, smuts and rust (Ullah 2018). Previously about 180 species of rust fungi have been reported from this area (Afshan \& Khalid 2009, Afshan et al. 2008, Ishaq et al. 2013, Ullah et al. 2014, Fiaz et al. 2017, Ullah 2018). During the exploration of Uredinales of Khyber Pakhtunkhwa, rust infected plants were collected from two different areas, Battagram and Shangla Districts. Among these Phragmidium mexicanum is reported here as a new record for Pakistan.

\section{Materials \& Methods}

Freehand sections and sori of infected plant materials were mounted in lactic acid. The plants were photographed and infected portions were observed using a stereomicroscope. At least 20 spores of each spore state were examined using the microscope (Nikon YS 100) and paraphyses and spore dimensions were made using an ocular micrometer (Zeiss Eyepiece Screw Micrometer). Sections and spores were microphotographed by digiporo-Labomed. Illustrations were made using a Lucida camera (Ernst LeitzWetzlar Germany). The rusted specimens have been deposited in the herbarium of the Botany Department, at Hazara University Mansehra (KP) (HUP).

\section{Results and Discussion}

Phragmidium mexicanum (Mains) H.Y. Yun, Minnis \& Aime, Mycologia 103: 1452 (2011)

(Figs 1, 2) 
Spermogonia and aecia not observed. Uredinia yellowish, abaxial, subepidermal, circular, pale yellow, 0.5-0.9 $\mathrm{mm}$ in diameter. Urediniospores $19-24 \times 18-22.5 \mu \mathrm{m}$, globoid to obovoid, contents yellowish, wall hyaline, 1.2-1.9 $\mu \mathrm{m}$ thick, pores indistinct. Telia yellowish or red, abaxial, subepidermal, circular, 0.8-0.5 mm diameter. Paraphyses absent. Teliospores 49-94 $\times 25-35 \mu \mathrm{m}$, fusiform or cylindrical, sometimes slightly curved, apex obtuse, tapering to an obtuse base, 2-7celled, mostly yellowish, wall smooth, $3-5 \mu \mathrm{m}$ thick at apex, $0.9-2.8 \mu \mathrm{m}$ thick at sides; pores one per cell, central and apical in apical cells, immediately below septa in subapical cells, pedicels of constant width, or little tapering below, yellowish above, hyaline below, up to $60 \mu \mathrm{m}$ long.

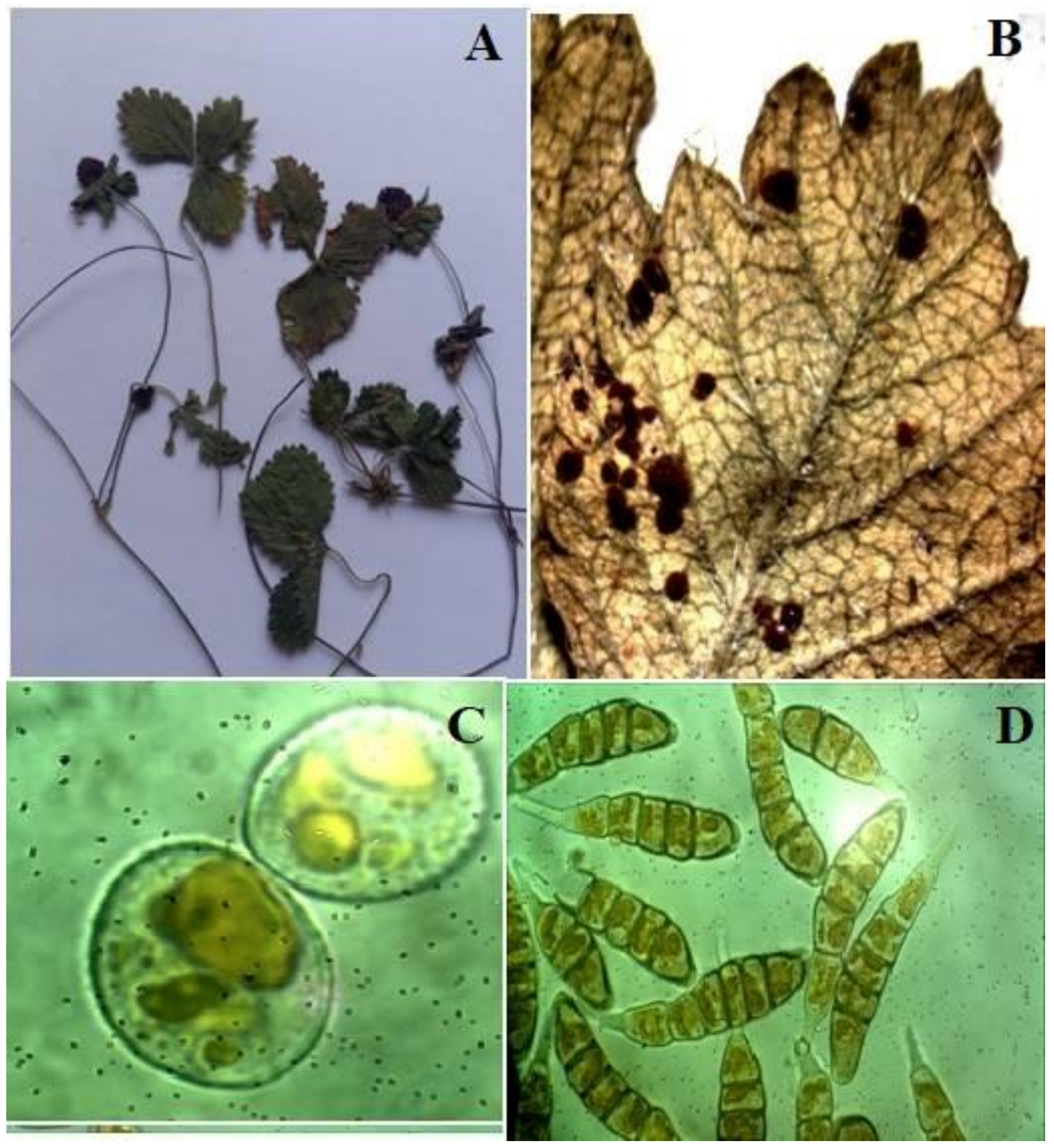

Fig. 1 - Phragmidium mexicanum on Duchesnea indica. A Infected leaves of host plant. $B$ Uredinia and telia on abaxial leaf surface. C Urediniospores. D Teliospores. Scale bars $A=3 \mathrm{~cm}$, $\mathrm{B}=10 \mathrm{~mm}, \mathrm{C}=10 \mu \mathrm{m}, \mathrm{D}=13 \mu \mathrm{m}$. 
Material examined - Pakistan, KP Province, District Battagram, Allai, on Duchesnea indica with stage II and III, $1800 \mathrm{~m}$ a, s, l., August 2016, Muhammad Fahd MF101 (HUP-MF101); District Shangla, Kormang, on Duchesnea indica with stage II and III, at $2000 \mathrm{~m}$ a, s, 1., September 2014, Sadiq Ullah SUR500 (HUP-RSU500).

Notes - Arthur (1912) was the first to recognize this taxon as a distinctive species, describing it as Kuehneola duchesneae on Duchesnea indica. McCain \& Hennen (1990) provided a taxonomic and nomenclatural revision of this species, and recognized two varieties, $F$. mexicana var. mexicana and $F$. mexicana var. indicae, which were differentiated primarily by the number of cells per teliospore. Because McCain \& Hennen (1990) treated the Mains (1939) species based on Frommea mexicana and the Arthur (1912) species based on Kuehneola duchesneae as a single species with two varieties the new teleomorphic name, Frommeella mexicana var. indicae, had to be introduced at that time because all homotypic synonyms of the Arthur name were based on a type specimen bearing only the anamorphic, uredinial stage, in spite of Arthur (1912) describing a telial state. Currently, one species, Phragmidium mexicanum, with no varieties is recognized because the presence or absence of uredinial paraphyses was variable in the studied material and no sequence differences were found that would warrant the recognition of two infraspecific taxa (Yun et al. 2011). Arthur (1925) similarly noted the variable presence or absence of uredinial paraphyses in this species. Additionally, in the material on Duchesnea indica examined by Yun et al. 2011, five-celled teliospores were not consistently encountered. Based on the anamorphic nature of the type specimen of Kuehneola duchesneae that was reported by McCain \& Hennen (1990), Yun et al. (2011) proposed the new combination Phragmidium mexicanum for this fungus. Previously this species has been reported from Europe, USA, South America, China, Australia, New Zealand and Korea (Yun et al. 2011). This is the first report from Pakistan.
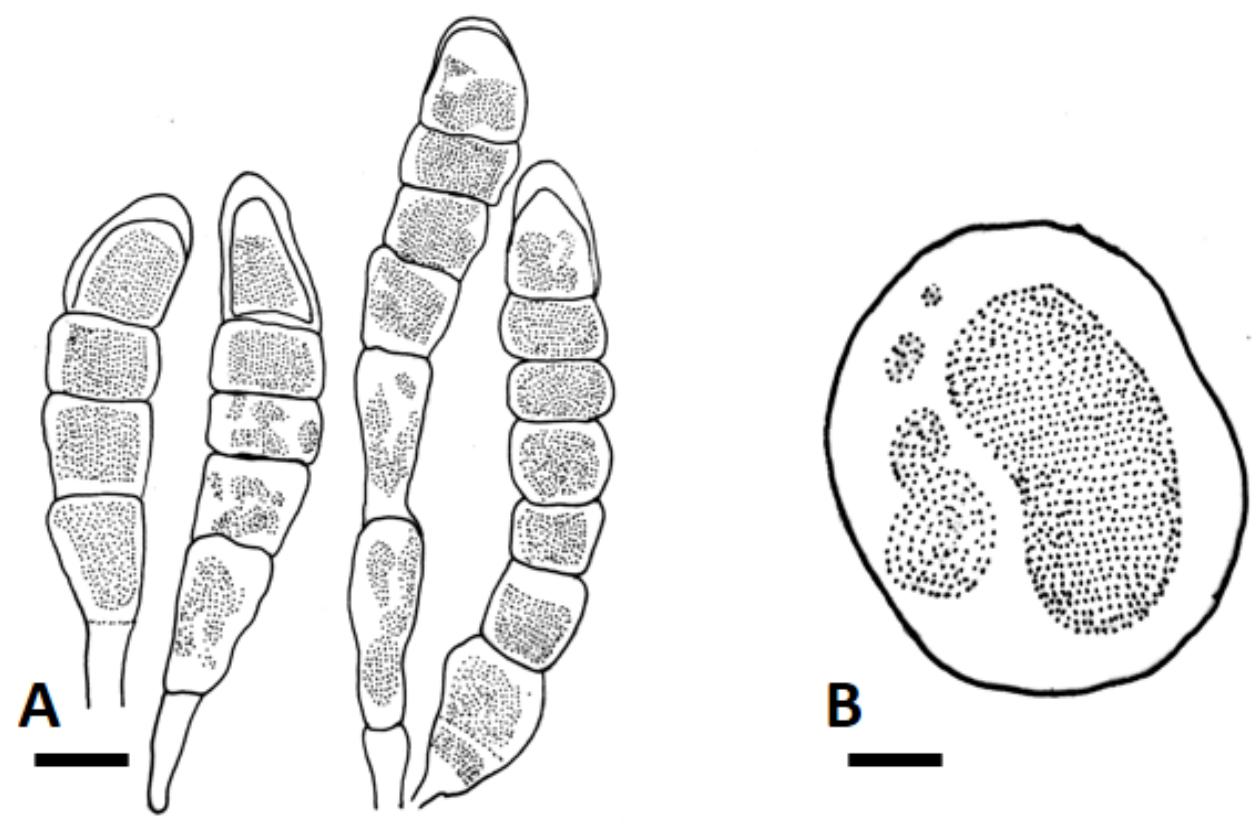

Fig. 2 - Phragmidium mexicanum Line drawing of A Teliospores and B urediniospores. Scale bars $\mathrm{A}=18 \mu \mathrm{m}, \mathrm{B}=8 \mu \mathrm{m}$.

\section{References}

Afshan NS, Khalid AN, Niazi AR. 2008 - New records and distribution of rust fungi from Pakistan. Mycotaxon 105, 257-267.

Afshan NS, Khalid AN. 2009 - New records of Puccinia and Pucciniastrum from Pakistan. Mycotaxon 108, 137-146. 
Arthur JC. 1912 - Order Uredinales. North American Flora 7, 161-268.

Arthur JC. 1925 - Order Uredinales. North American Flora 7, 669-732.

Fiaz M, Habib A, Najam US. 2017 - New reports and host records of rust fungi from Pakistan. Bangladesh Journal of Botany 46(1), 73-81.

Ishaq A, Afshan NS, Khalid AN. 2013 - New records of Puccinia on Poaceae from Khyber Pakhtunkhwa, Pakistan. Mycotaxon 126, 177-182.

Mains EB. 1939 - New and unusual species of Uredinales. Bulletin Torrey Botanical Club 66, 617621.

McCain JW, Hennen JF. 1990 - Taxonomic notes on Frommeëlla (Uredinales)-1. Mycotaxon 39, 249-256.

Ullah S, Ishaq A, Fiaz M, Afshan NS, Khalid AN. 2014 - A new report of Uromyces ambiens on box plant from Pakistan. Mycotaxon 129, 429-432.

Ullah S. 2018 - Studies on Diversity of Basidiomycetes of District Shangla. PhD Thesis, Department of Botany, Hazara University Mansehra, Pp. 10-20.

Yun HY, Minnis AM, Kim YH, Castlebury LA, Aime MC. 2011 - The rust genus Frommeëlla revisited: a later synonym of Phragmidium after all. Mycologia 103(6), 1451-1463. 